\title{
A ractopamine electrochemical sensor based on a 3-dimensional macroporous copper electrode modified with a gold coating
}

Yan $\mathrm{Ji}^{1}$, Yuhui $\mathrm{Du}{ }^{1}$, Ling Jia ${ }^{1}$, Hong $\mathrm{Li}^{3,4,5, *}$, Jiping $\mathrm{An}^{2, *}$ and Bin $Q i^{1, *}$

${ }^{1}$ Faculty of Chemistry, Northeast Normal University, Changchun, 130024, China

${ }^{2}$ Hospital of Stomatology, Jilin University, Changchun, 130024, China

${ }^{3}$ Key Laboratory of Narcotics Assay and Control Technology, Ministry of Public Security

${ }^{4}$ Public Security Department of Yunnan Province, Kunming, 650220, China

${ }^{5}$ Institute of Forensic Science, Ministry of Public Security, P. R. China

*E-mail: qib219@nenu.edu.cn

doi: $10.20964 / 2020.04 .16$

Received: 9 December 2019 / Accepted: 31 January 2020 / Published: 10 March 2020

Within this work, the direct electrooxidation of $\mathrm{Rac}$ on $\mathrm{Cu}$ was explored. To enhance the performance of $\mathrm{Cu}$, three hard coatings were investigated: (1) a $\mathrm{Au}$ coating ( $\mathrm{Au} @ \mathrm{Cu}$ ) formed via an electrodeposition process; (2) a 3D-macroporous $\mathrm{Cu}(3 \mathrm{D}-\mathrm{Cu})$ formed by the electrodeposition of $\mathrm{Cu}$ (from $\mathrm{CuSO}_{4}$ ), on a bare $\mathrm{Cu}$ surface with $\mathrm{H}_{2}$ bubbles as a template; and (3) a Au-coated 3D$\mathrm{Cu}(\mathrm{Au} @ \mathrm{Cu} 3 \mathrm{D})$ prepared by an electrodeposition method. Bare $\mathrm{Cu}$ was used as a reference for performance comparison. Au@Cu3D was found to demonstrate the best analytical performance towards the determination of Rac. The detection limit, linear range, reproducibility, stability and real sample analysis results were used to evaluate the analytical abilities of the samples.

Keywords: Ractopamine, electrochemistry, gold coating, $\mathrm{Cu}$

\section{FULL TEXT}

(C) 2020 The Authors. Published by ESG (www.electrochemsci.org). This article is an open access article distributed under the terms and conditions of the Creative Commons Attribution license (http://creativecommons.org/licenses/by/4.0/). 